\title{
Kırşehir Yerel Sivri Biber (Capsicum annuum L. var. longum) Populasyonlarının Agronomik ve Morfolojik Karakterizasyonu
}

\author{
Hakan BAŞAK (iD) \\ Kırşehir Ahi Evran Üniversitesi Ziraat Fakültesi Bahçe Bitkileri Bölümü, Kırşehir \\ https://orcid.org/0000-0002-1128-4059 \\ $\bowtie$ : hbasak@ahievran.edu.tr
}

\section{ÖZET}

2014 ve 2015 yıllarında yürütülen çalışmada Kırşehir ili merkez ve köylerinden toplanan; 2014 yılı için 240, 2015 yılı için ise 313 biber genotipi içerisindeki 99 adet sivri biber genotipi fide çıkışından vejetasyon süresi sonuna kadar, toplam 48 agronomik ve morfolojik özellik bakımından, IPGRI'nin biber için yayınlamış olduğu tanımlama listesi ve UPOV kriterlerine göre karakterizasyon çalışması yapılmıştır. İncelenen karakterlerin minimum, maksimum, ortalama değerleri ve frekans yüzdeleri belirlenmiştir. Popülasyonlar arasındaki ilişkinin belirlenmesi amacı ile küme ve temel bileşen analizi uygulanmıştır. Uygulanan temel bileşen analizi sonucunda toplam 17 adet ana bileşen ekseni elde edilmiş ve bu eksenler toplam varyansın \% 75.82'sini temsil etmiştir. Morfolojik ve agronomik özelliklere göre genotipler dendrogramda 15 gruba ayrılmıştır. Küme analizi sonucunda; S1, S2, S62, S3, S9, S67 ve TR69737 kodlu genotiplerin agronomik ve morfolojik akrabalık derecesi bakımından birbirine en uzak genotipler olduğu belirlenmiştir. Daha önce üzerinde hiçbir çalışma yapılmamış olan Kırşehir ili sivri biber genotiplerinin tanımlanmasının yapılması ile belirlenen biber popülasyonlarındaki genetik varyasyon gelecekte yapılacak biber ıslah çalışmalarında önemli avantajlar sağlayacaktır.

Araştırma Makalesi
$\begin{aligned} & \text { Makale Tarihçesi } \\ & \text { Geliş Tarihi } \quad: 27.11 .2018 \\ & \text { Kabul Tarihi } \quad: 17.01 .2019\end{aligned}$

Anahtar Kelimeler
Kırşehir
Biber
Populasyon
Karakterizasyon
Morfolojik

Agronomic and Morphological Characterization of Kırşehir Local Green Long Pepper (Capsicum annuum L. var. longum) Populations
ABSTRACT
In this study conducted in 2014 and 2015, genotypes were collected from the center and villages of Kırşehir province. Overall, 99 green long pepper genotypes within 313 pepper genotypes were characterized from the emerging of seedling to the end of the vegetation period, in terms of 48 agronomic and morphological characteristics based on IPGRI's description list for pepper and the UPOV criteria. The minimum, maximum, mean values and frequency percentages of the studied characters were determined. In order to determine the relationship between populations, cluster and principal component analysis were applied. As a result of the principal component analysis, total 17 main component axes were obtained and these axes represented $75.82 \%$ of the total variance. Genotypes were categorized into 15 groups in dendrogram according to morphological and agronomic characteristics. As a result of cluster analysis; S1, S2, S62, S3, S9, S67 and TR69737 coded genotypes were determined to be the most distant genotypes in terms of agronomic and morphological degree of relation. Up to now, with no similar study has been done before, the genetic variation in pepper populations determined by the identification of green long pepper genotypes of Kırşehir province will provide significant advantages in future pepper breeding studies.

\section{Research Article}

$\begin{array}{ll}\text { Article History } & \\ \text { Received } & : 27.11 .2018 \\ \text { Accepted } & : 17.01 .2019\end{array}$

Keywords

Kırşehir

Pepper

Population

Characterization

Morphological

To Cite : Başak H 2019. Kırşehir Yerel Sivri Biber (Capsicum annuum L. var. longum) Populasyonlarının Agronomik ve Morfolojik Karakterizasyonu. KSÜ Tarım ve Doğa Derg 22(2): 202-216. DOI: 10.18016/ksutarimdoga.vi.488204. 


\section{GİRİ̧̧}

Türkiye sebze yetiştiriciliğinde önemli bir yeri olan biber (Capsicum annuum L.), ülkemizin farklı ekolojilerinde geniş alanlarda yetiştirilmektedir. Biberin anavatanın Amerika kitasının tropik ve subtropik ülkeleri olduğu bilinmektedir (Şalk ve ark., 2008). Dünyada toplam 32.324.345 ton biber üretimi gerçekleştirilirken, Türkiye 2.127.944 ton biber üretim miktarı ile Çin ve Meksika'dan sonra \% 6.6'lık toplam üretim içerisindeki payı ile 3. sırada yer almaktadır (FAO, 2014).

Kırşehir ilinin toplam 281.766 ha tarım yapılan alanının 1.906 ha'ında sebze tarımı yapılmakta olup, toplam tarım yapılan alanın \% 0.67'sinde sebze tarımı yapılmaktadır. Kırşehir ilinde toplam 179 ha alanda 1.316 ton biber üretimi gerçekleşmiştir. Özellikle Kırşehir ilinde yetiştirilen sebzeler arasında \% 9.3 pay ile dolmalık biber üretimi başı çekmektedir (TUİK, 2017). Kırşehir İli üretim kapasitesi bakımından biber yetiştiriciliğinin yoğun yapıldığı bir şehir olmasa da, üretici koşullarında yerel genotipler ticari çeşitlere göre daha yaygın olarak kullanılmaktadır. Bölge üreticisi sebzeciliği ana geçim kaynağı olarak değil, daha çok ihtiyaç fazlasını pazara sunmak şeklinde aile işletmeciliği modeli ile yaptığından, tohumluğunu kendi üretmekte ya da takas yoluyla komşusundan temin etmektedir.

Yerel biber popülasyonlarında zaman içerisinde seleksiyonlar ve doğal melezlemeler ile oluşan farklı bitki ve meyve yapısına sahip genotipler, bitki genetik kaynaklarındaki genotip sayısının her geçen gün artmasına neden olmuşlardır (Haussmann ve ark., 2004; Zhang ve ark., 2016). Eşsiz hazine olarak değerlendirilen bu genetik kaynaklar, özellikle bitki ıslah çalışmalarında yeni çeşitlerin geliştirilebilmesi ve genetik varyasyonun oluşturulabilmesi yönünden önemli gen havuzlarıdır (Bliss, 1981). Üreticilerin kendi tohumluğunu temin etmesinin yaygin olduğu Kırşehir ilinde, biber bitkisinde yüksek düzeyde görülen yabancı döllenmenin de etkisiyle, zaman içerisinde genotip çeşitliliğinde artış oluşmuştur.

Yerel çeşitleri ıslah çalışmalarında değerli kılan en önemli özellikleri; yüksek adaptasyon yetenekleri, hastalık ve zararlılara dayanıklılıkları ve istenilen birçok kalite özelliğine sahip olmalarıdır (Küçük, 1996). Bu özellikleri sayesinde uzun yıllar üretici koşullarında nesillerini devam ettirerek günümüze kadar ulaşmayı başarmışlardır. Zengin bir biyoçeşitliliğe sahip olunmasına rağmen, değişik sebeplerden dolayı var olan bitkisel çeşitlilik zamanla azalmakta veya kaybolmaktadır. Tüm bitkiler için önemli olsa da, özellikle tarımı yapılan türlerde genetik kaynaklardaki çeşitliliğin korunması, sürdürülebilirlik bakımından önemlidir (Tan ve İnal, 2003). Çeşit sayısındaki azalmanın farkına varan pek çok ülke bitkisel kaynakların belirlenmesi, korunması ve muhafazasına yönelik çalışmalar başlatmışlardır (Tan, 1992). Biyoçeşitliliği korumak için öncelikle iyi planlanmış surveyler ile materyallerin toplanması ve toplanan materyallerin gen bankalarında muhafaza edilmesi gerekmektedir. Ancak özellikleri tanımlanmamış bir materyalin sadece muhafaza edilmesi onun ıslah çalışmalarında değerlendirilme şansını azaltmaktadır. Özellikleri tanımlanmış, karakterize edilmiş materyallerle çalışmak ıslah çalışmalarında süreyi önemli ölçüde azaltarak, maliyetleri de düşürmektedir.

$\mathrm{Bu}$ çalışmada, üzerinde daha önce hiçbir çalışma yapılmamış olan, Kırşehir sivri biber popülasyonlarındaki mevcut genetik varyasyonun varlığı ve boyutlarının saptanması ile Kırşehir İli biber veri tabanının oluşturulması amaçlanmıştır.

\section{MATERYAL ve YÖNTEM}

Çalışmada materyal olarak kullanılan biber genotipleri, Kırşehir İl sınırları içindeki yer alan 7 İlçe ve bu İlçelere bağlı 89 belde ve köy noktasından çiftçilerden tohum şeklinde veya üretim alanlarından meyve olarak toplanmıştır. Materyal toplamak amacıyla yapılan surveyler sonucu toplanan farklı biber tiplerini (Sivri, dolma, yağlık ve süs) içeren 313 adet genotip içerisinden 99 adet sivri biber genotipi seçilerek agronomik ve morfolojik karakterizasyonu yapılmıştır.

Ayrıca, Ege Tarımsal Araştırma Enstitüsü (ETAE)'nden Kırşehir ilinden daha önce toplanmış fakat tanımlanması yapılmamış 3 adet sivri biber genotipi temin edilmiştir. Denemenin hem birinci hem de ikinci yılında genotipleri kıyaslamak amacıyla 19 adet Türkiye'de yoğun olarak yetiştirilen ticari sivri biber çeşitleri de materyaller içerisinde yer almıştır. Çalışmada materyal olarak kullanılan genotiplerin farklı sivri biber meyve tiplerini içermesinden dolayı, ticari çeşitlerin de sayısı yüksek tutularak kıyaslamanın daha sağlıklı yapılabilmesine çalışılmıştır. $\mathrm{Bu}$ sayede belirlenen varyasyonun bölgeye giren ticari çeşitlerden kaynaklanıp kaynaklanmadığı da öngörülebilecektir.

\section{Denemenin Kurulması}

Araştırma 2014 ve 2015 yıllarında Kırşehir Ahi Evran Üniversitesi Ziraat Fakültesi Bahçe Bitkileri Bölümü'nde yürütülmüştür. Seçilen genotiplere ait tohumlar 3:1 oranında torf+perlit karışımı doldurulmuş 45'lik viyollere ilk yıl 18.03.2014 tarihinde, ikinci yıl 25.03.2015 tarihinde ekilmiş; çıkış yapan fideler, asıl yerlerine aktarılıncaya kadar geçen sürede Vural ve ark., (2000)'nın önerdiği şekilde bakım işlemleri uygulanmıştır. Dikime hazır hale gelen fideler ilk yl 07.05.2014 tarihinde ve ertesi yıl 10.05.2015 tarihinde her parselde aynı genotipten 20 bitki olacak şekilde ve $70 \times 40 \mathrm{~cm}$ mesafelerde 
dikilmiştir.

Denemenin yürütüldüğü 2014 ve 2015 yılları uzun yıllar ortalama iklim verileri Çizelge 1 de; deneme alanının toprak analizi sonuçları ise Çizelge 2'de verilmiştir. Bitkiler damlama sulama sistemi ile 2-3 gün aralıklarla sulanmış ve gübreleme deneme süresince fertigasyon yöntemi ile yapılmıştır. Gübreleme toprak analiz sonuçları dikkate alınarak her iki yılda da; $12 \mathrm{~kg} \mathrm{da}^{-1} \mathrm{~N}, 5 \mathrm{~kg} \mathrm{da}^{-1} \mathrm{P}, 15 \mathrm{~kg} \mathrm{da}^{-1} \mathrm{~K}$, $5 \mathrm{~kg} \mathrm{da}{ }^{-1} \mathrm{Ca}$ ve $3 \mathrm{~kg} \mathrm{da}^{-1} \mathrm{Mg}$ olacak şekilde uygulanmıştır (Şalk ve ark., 2008)..

Çizelge 1. Kırşehir İli uzun yıllar (1930-2016) ve 2014 - 2015 yılları meteorolojik verileri

\begin{tabular}{llllllllll} 
& \multicolumn{3}{c}{ Ortalama Sicaklık $\left({ }^{\circ} \mathrm{C}\right)$} & \multicolumn{3}{c}{ Toplam Yağış $(\mathrm{mm})$} & \multicolumn{3}{c}{ Ortalama Nispi Nem $(\%)$} \\
\hline Aylar & Uzun yıllar & 2014 & 2015 & Uzun yıllar & 2014 & 2015 & Uzun ylllar & 2014 & 2015 \\
\hline Mayıs & 15.3 & 16.3 & 15.9 & 44.8 & 46.6 & 39.2 & 60.7 & 60.8 & 57.8 \\
Haziran & 19.7 & 19.9 & 18.3 & 33.9 & 36.0 & 161.4 & 54.2 & 53.6 & 66.9 \\
Temmuz & 23.2 & 25.5 & 23.1 & 6.6 & 13.0 & 20.6 & 48.2 & 38.4 & 46.3 \\
Ağustos & 22.9 & 25.9 & 24.7 & 5.0 & 17.0 & 11.8 & 48.4 & 39.4 & 47.0 \\
Eylül & 18.3 & 19.8 & 23.0 & 12.0 & 29.8 & 1.0 & 52.9 & 51.2 & 40.4 \\
Ort./Top. & 19.88 & 16.39 & 21.0 & 102.3 & 172.4 & 234 & 52.88 & 48.68 & 51.68 \\
\hline
\end{tabular}

Değerler Meteoroloji Genel Müdürlügünden Alınmıştır.

Çizelge 2. Deneme alanı toprağının bazı kimyasal ve fiziksel analiz sonuçları

\begin{tabular}{|c|c|c|c|c|c|c|c|}
\hline \multicolumn{8}{|c|}{ Fiziksel analiz sonuçları } \\
\hline \multirow{3}{*}{$\begin{array}{l}\text { Derinlik } \\
(\mathrm{cm})\end{array}$} & \multirow{2}{*}{\multicolumn{3}{|c|}{$\begin{array}{l}\text { Taneciklerin dağılımı } \\
(\%)\end{array}$}} & \multirow{3}{*}{$\begin{array}{l}\text { Bünye } \\
\text { sinifi }\end{array}$} & \multirow{3}{*}{$\begin{array}{l}\text { Tarla } \\
\text { Kapasitesi } \\
\left(\mathrm{g} \mathrm{g}^{-1} ; \%\right)\end{array}$} & \multirow{3}{*}{$\begin{array}{l}\text { Solma } \\
\text { Noktası } \\
\left(\mathrm{g} \mathrm{g} \mathrm{g}^{-1} ; \%\right)\end{array}$} & \multirow{3}{*}{$\begin{array}{l}\text { Toprağın } \\
\text { Hacim Ağırlığı } \\
\left(\mathrm{g} \mathrm{cm}^{3}\right)\end{array}$} \\
\hline & & & & & & & \\
\hline & Kum & Silt & Kil & & & & \\
\hline $0-30$ & 41.7 & 23.6 & 34.7 & Killi-tınlı & 30.39 & 14.13 & 1.29 \\
\hline $30-60$ & 41.8 & 18.2 & 40.0 & Killi-tınlı & 32.42 & 16.85 & 1.27 \\
\hline \multicolumn{8}{|c|}{ Kimyasal analiz sonuçları } \\
\hline \multirow[t]{2}{*}{$\begin{array}{l}\text { Derinlik } \\
(\mathrm{cm})\end{array}$} & \multirow[t]{2}{*}{$\mathrm{pH}$} & \multirow[t]{2}{*}{$\begin{array}{l}\text { ToplamTuz } \\
\text { (\%) }\end{array}$} & \multirow[t]{2}{*}{$\begin{array}{l}\text { EC } \\
\left(\mathrm{dS} \mathrm{m}^{-1}\right)\end{array}$} & \multirow[t]{2}{*}{$\begin{array}{l}\text { Kireç } \\
(\%)\end{array}$} & \multicolumn{2}{|c|}{$\begin{array}{l}\text { Yarayışlı besin maddeleri } \\
\left(\mathrm{kg} \mathrm{ha}^{-1)}\right.\end{array}$} & $\begin{array}{l}\text { Organik madde } \\
(\%)\end{array}$ \\
\hline & & & & & $\mathrm{P}_{2} \mathrm{O}_{5}$ & $\mathrm{~K}_{2} \mathrm{O}$ & \\
\hline $0-30$ & 7.75 & 0.019 & 0.556 & 31.01 & 48.3 & 657.2 & 0.78 \\
\hline $30-60$ & 7.46 & 0.062 & 1.643 & 31.16 & 16.9 & 281.3 & 0.69 \\
\hline
\end{tabular}

* Killi tınlı (CL) ; Kaynak: Ankara Toprak Gübre Su Kaynakları Araştırma Merkezi

Agronomik ve Morfolojik Karakterizasyon Çalışması

Çalışmanın agronomik ve morfolojik tanımlama aşamasında Çizelge 3'de ayrıntılı olarak verilen IPGRI (Uluslararası Bitki Genetik Kaynakları Araştırma Enstitüsu) ve UPOV (Uluslararası Yeni Bitki Çeşitlerini Koruma Birliği) tarafından geliştirilen özellik belgelerindeki kriterlerden yararlanılmıştır (Anonymous,1994). Fide, bitki, gövde, yaprak, çiçek ve meyve kısımlarında gerçekleştirilen; 8 adeti kalitatif (QL: Qualitative characteristic), 32 adeti kantitatif (QN: Quantitative characteristic) ve 8 adeti yalanc1 kalitatif (PQ: Pseudo-qualitative characteristic) olmak üzere toplam 48 özellik değerlendirilmiştir (Çizelge 4). Karakterizasyon çalışmaları için her populasyondaki 10 bitki ele alınmıştır. Çalışmada incelenen karakterlerin (ölçülebilir) minimum, maksimum, ortalama değerleri ve frekans yüzdeleri belirlenmiştir.

\section{Laboratuvar Çalışmaları}

Meyve uzunluğu, meyve çapı, meyve eti kalınlığı, meyve sapı uzunluğu ve çapı, meyvede acılık varlığı, SÇKM ve etüvde kuru madde ölçümleri laboratuvarda gerçekleştirilmiştir. Meyve ölçümlerinde cetvel ve dijital kumpas; SÇKM (\%) belirlemelerinde her bir genotipteki meyvelerin benzer yerlerinden alınan parçaların suyu alınarak dijital refraktometre (Hanna HI 96801) kullanılmıştır.

Kuru madde miktarı belirlemesinde Bozokalfa ve ark., (2009)'ina göre hareket edilmiş, genotiplere ait meyvelerin etüvde $60^{\circ} \mathrm{C}$ 'de sabit ağırlı̆̆a gelinceye kadar bekletildikten sonraki örnekleri dikkate alınmıştır. Ayrıca her bir genotipe ait meyve örneklerinin milimetrik kağıt üzerinde ölçekli olarak fotoğrafları çekilerek Kırşehir İli biber genotipleri kataloğu oluşturulmuştur.

\section{Verilerin Istatistik Değerlendirilmesi}

Tesadüf blokları deneme desenine göre planlanan çalışmada, 2014 ve 2015 yıllarında elde edilen verilerin istatiksel olarak değerlendirilmesinde "SPSS (20)' ve JMP analiz paket programı kullanılmıştır. İki yılın veri setlerine önce Temel Bileşen Analizi (Principal Component Analysis (PCA)) uygulanmış ve genotiplere ait temel bileşen (PC) eksenleri elde edilmiştir (Sneath ve Sokal 1973). PC eksenleri ve bunlara ait varyasyon ve kümülatif varyasyon oranları ile özellik bazında ortaya çıkan temel bileşenlerdeki ağırlık değerlerini belirten faktör kat sayıları belirlenmiştir. 
Çizelge 3. Kırşehir yerel biber populasyonunda incelenen agronomik, morfolojik ve fenolojik özelliklerin frekans dağılımı

\begin{tabular}{|c|c|c|c|c|}
\hline UPOV & GÖZLEM YERİ & ÖZELLİKLER & DERECELEME & FREKANS ORANI(\%) \\
\hline \multirow[t]{2}{*}{1} & FİDE & Hipokotilde antosiyanin & YOK & 17.1 \\
\hline & & oluşumu & VAR & $\begin{array}{ll}9 & 92.9\end{array}$ \\
\hline \multirow[t]{3}{*}{2} & BİTKİ & Duruşu & DİK & 128.3 \\
\hline & & & YARI DİK & 270.7 \\
\hline & & & YATIK & 31.0 \\
\hline \multirow[t]{3}{*}{3} & BİTKİ & Gövde & KISA & 31.0 \\
\hline & & Uzunluğu (cm) & ORTA & $\begin{array}{ll}5 & 43.4\end{array}$ \\
\hline & & & UZUN & 755.6 \\
\hline \multirow[t]{2}{*}{4} & BİTKİ & Üst bölümde kısa & YOK & 19.1 \\
\hline & & boğumluluk & VAR & 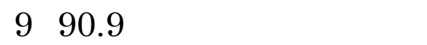 \\
\hline \multirow[t]{5}{*}{5} & BİTKİ & Ana sürgün üzerinde boğum & ÇOK KISA & 10.0 \\
\hline & & arası Uzunluğu $(\mathrm{cm})$ & KISA & 30.0 \\
\hline & & & ORTA & 53.0 \\
\hline & & & UZUN & 762.6 \\
\hline & & & ÇOK UZUN & $\begin{array}{ll}9 & 34.3\end{array}$ \\
\hline \multirow[t]{2}{*}{6} & BİTKİ & Boğumlarda antosiyanin & YOK & 11.0 \\
\hline & & & VAR & 999.0 \\
\hline \multirow[t]{5}{*}{7} & GÖVDE & Boğumlarda antosiyanin & ÇOK ZAYIF & 11.0 \\
\hline & & renklenmesi yoğunluğu & ZAYIF & $\begin{array}{ll}3 & 17.2\end{array}$ \\
\hline & & & ORTA & $\begin{array}{ll}5 & 68.7\end{array}$ \\
\hline & & & GÜÇLÜ & $\begin{array}{ll}7 & 11.1\end{array}$ \\
\hline & & & ÇOK GÜÇLÜ & 92.0 \\
\hline \multirow[t]{5}{*}{8} & GÖVDE & Boğumlarda tüylülük & YOK-ÇOK ZYF & 10.0 \\
\hline & & & ZAYIF & 398.0 \\
\hline & & & ORTA & 52.0 \\
\hline & & & GÜÇLÜ & 70.0 \\
\hline & & & ÇOK GÜÇLÜ & 90.0 \\
\hline \multirow[t]{5}{*}{9} & BİTKİ & Uzunluk (cm) & ÇOK KISA & 10.0 \\
\hline & & & KISA & 32.0 \\
\hline & & & ORTA & $\begin{array}{ll}5 & 68.7\end{array}$ \\
\hline & & & UZUN & $\begin{array}{ll}7 & 29.3\end{array}$ \\
\hline & & & ÇOK UZUN & 90.0 \\
\hline \multirow[t]{5}{*}{10} & YAPRAK & Uzunluğu (cm) & ÇOK KISA & 13.0 \\
\hline & & & KISA & $\begin{array}{ll}3 & 93.9\end{array}$ \\
\hline & & & ORTA & 53.0 \\
\hline & & & UZUN & 70.0 \\
\hline & & & ÇOK UZUN & 90.0 \\
\hline \multirow[t]{4}{*}{11} & YAPRAK & Genişliği (cm) & ÇOK DAR & 11.0 \\
\hline & & & DAR & $\begin{array}{ll}3 & 69.7\end{array}$ \\
\hline & & & ORTA & $\begin{array}{ll}5 & 28.3\end{array}$ \\
\hline & & & GENIŞ & $7 \quad 1.0$ \\
\hline \multirow[t]{5}{*}{12} & YAPRAK & Yeşil renk tonu & ÇOK AÇIK & 10.0 \\
\hline & & & AÇIK & $\begin{array}{ll}3 & 13.1\end{array}$ \\
\hline & & & ORTA & $\begin{array}{ll}585.9 \\
-1\end{array}$ \\
\hline & & & KOYU & 71.0 \\
\hline & & & ÇOK KOYU & 90.0 \\
\hline \multirow[t]{3}{*}{13} & YAPRAK & Şekli & MIZRAK ŞEKİLDE & 120.2 \\
\hline & & & OVAL ŞEKİLDE & 279.8 \\
\hline & & & GENİŞ ELİPS & 30.0 \\
\hline \multirow[t]{5}{*}{14} & YAPRAK & Kenardaki dalgalanma & YOK-ÇOK ZAYIF & 110.1 \\
\hline & & & ZAYIF & $\begin{array}{ll}3 & 86.9\end{array}$ \\
\hline & & & ORTA & 53.0 \\
\hline & & & GÜÇLÜ & $\begin{array}{ll}7 & 0.0\end{array}$ \\
\hline & & & ÇOK GÜÇLÜ & 90.0 \\
\hline
\end{tabular}




\begin{tabular}{|c|c|c|c|c|c|c|c|c|c|}
\hline \multirow{5}{*}{\multicolumn{2}{|c|}{15}} & & & & & YAPRAK & Kabarcık & COK ZAYIF & 123.2 \\
\hline & & & & & & & & ZAYIF & 374.7 \\
\hline & & & & & & & & ORTA & 52.0 \\
\hline & & & & & & & & GÜÇLÜ & 70.0 \\
\hline & & & & & & & & ÇOK GÜÇLÜ & 90.0 \\
\hline \multirow{5}{*}{\multicolumn{2}{|c|}{16}} & & & & & YAPRAK & Enine kesitin şekli & GÜÇLÜ İÇ BÜKEY & 137.4 \\
\hline & & & & & & & & YUMUŞAK İÇ BÜKEY & 360.6 \\
\hline & & & & & & & & DÜZ & 52.0 \\
\hline & & & & & & & & YUMUŞAK DIŞ BÜKEY & 70.0 \\
\hline & & & & & & & & GÜÇLÜ DIŞ BÜKEY & 90.0 \\
\hline \multirow{5}{*}{\multicolumn{2}{|c|}{17}} & & & & & YAPRAK & Mumsuluk & ÇOK ZAYIF & 15.1 \\
\hline & & & & & & & & ZAYIF & $\begin{array}{ll}3 & 92.9\end{array}$ \\
\hline & & & & & & & & ORTA & 52.0 \\
\hline & & & & & & & & GÜÇLÜ & 70.0 \\
\hline & & & & & & & & ÇOK GÜÇLÜ & 90.0 \\
\hline \multirow{3}{*}{\multicolumn{2}{|c|}{18}} & & & & & ÇİÇEK & Sapın duruşu & DİK & 13.0 \\
\hline & & & & & & & & YARI SARKIK & 247.5 \\
\hline & & & & & & & & SARKIK & 349.5 \\
\hline \multirow{2}{*}{\multicolumn{2}{|c|}{19}} & & & & & ÇİÇEK & Anterlerde antosiyanin & YOK & 11.0 \\
\hline & & & & & & & renklenmesi & VAR & 999.0 \\
\hline \multirow{4}{*}{\multicolumn{2}{|c|}{20}} & & & & & & Fizyolojik olgunluk öncesi & YEŞİLIMSİ BEYAZ & 10.0 \\
\hline & & & & & & MEYVE & renk & SARI & 21.0 \\
\hline & & & & & & & & YEŞİL & 398.0 \\
\hline & & & & & & & & MOR & 41.0 \\
\hline \multirow{5}{*}{\multicolumn{2}{|c|}{21}} & & & & & MEYVE & Fizyolojik olgunluk öncesi & ÇOK AÇIK & $\begin{array}{ll}1 & 12.1\end{array}$ \\
\hline & & & & & & & renk yoğunluğu & AÇIK & $3 \quad 11.1$ \\
\hline & & & & & & & & ORTA & 538.4 \\
\hline & & & & & & & & KOYU & 735.4 \\
\hline & & & & & & & & ÇOK KOYU & 93.0 \\
\hline \multirow{2}{*}{\multicolumn{2}{|c|}{22}} & & & & & MEYVE & Antosiyanin renklenmesi & YOK & 193.9 \\
\hline & & & & & & & & VAR & 96.1 \\
\hline \multirow{3}{*}{\multicolumn{2}{|c|}{23}} & & & & & MEYVE & Duruşu & DİK & 12.0 \\
\hline & & & & & & & & YATAY & 227.3 \\
\hline & & & & & & & & SARKIK & $\begin{array}{ll}3 & 70.7\end{array}$ \\
\hline \multirow{5}{*}{\multicolumn{2}{|c|}{24}} & & & & & MEYVE & Uzunluğu (cm) & ÇOK KISA & 10.0 \\
\hline & & & & & & & & KISA & 32.0 \\
\hline & & & & & & & & ORTA & $\begin{array}{ll}5 & 39.4\end{array}$ \\
\hline & & & & & & & & UZUN & 753.5 \\
\hline & & & & & & & & ÇOK UZUN & 95.1 \\
\hline \multirow{5}{*}{\multicolumn{2}{|c|}{25}} & & & & & MEYVE & Çapı (mm) & ÇOK DAR & 172.7 \\
\hline & & & & & & & & DAR & 324.2 \\
\hline & & & & & & & & ORTA & 53.0 \\
\hline & & & & & & & & GENiş & 70.0 \\
\hline & & & & & & & & ÇOK GENIŞ & 90.0 \\
\hline \multirow{5}{*}{\multicolumn{2}{|c|}{26}} & & & & & MEYVE & Uzunluk / Çap oranı & ÇOK KÜÇÜK & 10.0 \\
\hline & & & & & & & & KÜÇÜK & 38.1 \\
\hline & & & & & & & & ORTA & $\begin{array}{ll}5 & 18.2\end{array}$ \\
\hline & & & & & & & & BÜYÜK & $7 \quad 44.4$ \\
\hline & & & & & & & & ÇOK BÜYÜK & 929.3 \\
\hline \multirow{8}{*}{\multicolumn{2}{|c|}{27}} & & & & & MEYVE & Uzunlamasına baskın şekli & KUTUPLARI YASSI & 10.0 \\
\hline & & & & & & & & YUVARLAK. & 20.0 \\
\hline & & & & & & & & KALP ŞEKLİNDE & 30.0 \\
\hline & & & & & & & & KARE & 40.0 \\
\hline & & & & & & & & DİKDÖRTGEN & 50.0 \\
\hline & & & & & & & & İKIZKENAR YAMUK & 60.0 \\
\hline & & & & & & & & HAFİ ÜÇGEN & 72.0 \\
\hline & & & & & & & & DAR ÜÇGEN & 878.8 \\
\hline
\end{tabular}




\begin{tabular}{|c|c|c|c|c|}
\hline \multirow{3}{*}{28} & \multirow{3}{*}{ MEYVE } & \multirow{4}{*}{$\begin{array}{l}\text { Plesanta seviyesinde enine } \\
\text { kesitte baskın şekil }\end{array}$} & BOYNUZ ŞEKLİNDE & $\begin{array}{ll}9 & 19.2\end{array}$ \\
\hline & & & ELİPS ŞEKLİNDE & 11.0 \\
\hline & & & KÖSELİ & 212.1 \\
\hline & & & YUVARLAK & 386.9 \\
\hline \multirow[t]{5}{*}{29} & \multirow[t]{5}{*}{ MEYVE } & Sapa yakın kısmında & YOK-ÇOK ZAYIF & 13.0 \\
\hline & & dalgalanma & ZAYIF & 327.3 \\
\hline & & & ORTA & 538.4 \\
\hline & & & GÜÇLÜ & 724.2 \\
\hline & & & ÇOK GÜÇLÜ & 97.1 \\
\hline \multirow[t]{5}{*}{30} & \multirow[t]{5}{*}{ MEYVE } & Sap haricinde dalgalanma & YOK-ÇOK ZAYIF & 18.1 \\
\hline & & & ZAYIF & 339.4 \\
\hline & & & ORTA & 537.4 \\
\hline & & & GÜÇLÜ & $7 \quad 10.1$ \\
\hline & & & ÇOK GÜÇLÜ & 95.1 \\
\hline \multirow[t]{4}{*}{31} & \multirow{4}{*}{ MEYVE } & Yüzey yapısı & DÜZ ÇOK HAFİF & 1414 \\
\hline & & & BURUŞUK & 141.4 \\
\hline & & & BİRAZ BURUȘUK & 255.6 \\
\hline & & & GÜÇLÜ BURUSŞUK & 33.0 \\
\hline \multirow[t]{5}{*}{32} & \multirow[t]{5}{*}{ MEYVE } & Olgunluk rengi & SARI & 10.0 \\
\hline & & & TURUNCU & 20.0 \\
\hline & & & KIRMIZI & 3100.0 \\
\hline & & & KAHVE & 40.0 \\
\hline & & & YESILL & 50.0 \\
\hline \multirow[t]{3}{*}{33} & \multirow{3}{*}{ MEYVE } & Fizyolojik olgunlukta renk & AÇIK & 336.4 \\
\hline & & yoğunluğu & ORTA & $5 \quad 56.6$ \\
\hline & & & KOYU & 77.1 \\
\hline \multirow[t]{5}{*}{34} & \multirow[t]{5}{*}{ MEYVE } & Parlaklık & ÇOK ZAYIF & 10.0 \\
\hline & & & ZAYIF & $\begin{array}{ll}3 & 31.3\end{array}$ \\
\hline & & & ORTA & 556.6 \\
\hline & & & GÜÇLÜ & $\begin{array}{ll}7 & 12.1\end{array}$ \\
\hline & & & ÇOK GÜÇLÜ & 90.0 \\
\hline \multirow[t]{2}{*}{35} & \multirow{2}{*}{ MEYVE } & Sapta oyukluk & YOK & 198.0 \\
\hline & & & VAR & 92.0 \\
\hline \multirow[t]{6}{*}{36} & MEYVE & Sapta oyukluk derecesi & YOK & 098.0 \\
\hline & & & ÇOK SIĞ & 10.0 \\
\hline & & & SIĞ & 32.0 \\
\hline & & & ORTA & 50.0 \\
\hline & & & DERIN & 70.0 \\
\hline & & & ÇOK DERIN & 90.0 \\
\hline 37 & MEYVE & Uç şekli & ÇOK KESKİN & 161.6 \\
\hline & & & HAFIF KESKIN & 236.4 \\
\hline & & & YUVARLAK & 30.0 \\
\hline & & & HAFIF BASIK & 40.0 \\
\hline & & & ÇOK BASIK & 50.0 \\
\hline 38 & MEYVE & Gözenekler arası oluk & YOK -ÇOK SIĞ & 150.5 \\
\hline & & derinliği & SIĞ & $3 \quad 36.4$ \\
\hline & & & ORTA & $5 \quad 12.1$ \\
\hline & & & DERIN & $7 \quad 1.0$ \\
\hline 39 & MEYVE & Lokul sayısı & AĞIRLIKLI İKİ & 164.6 \\
\hline & & & EŞİT İKİ VE ÜÇ & $\begin{array}{ll}2 & 19.2\end{array}$ \\
\hline & & & AĞIRLIKLI ÜÇ & $\begin{array}{ll}3 & 15.2\end{array}$ \\
\hline & & & EŞİT ÜC VE DÖRT & 41.0 \\
\hline 40 & MEYVE & Et kalınlığı $(\mathrm{mm})$ & ÇOK İNCE & 13.0 \\
\hline & & & INCE & 359.6 \\
\hline & & & ORTA & $\begin{array}{ll}5 & 33.3\end{array}$ \\
\hline & & & KALIN & 74.0 \\
\hline & & & ÇOK KALIN & $\begin{array}{ll}9 & 0.0\end{array}$ \\
\hline
\end{tabular}




\begin{tabular}{|c|c|c|c|c|}
\hline \multirow[t]{5}{*}{41} & MEYVE & Sap uzunluğu $(\mathrm{cm})$ & ÇOK KISA & 10.0 \\
\hline & & & KISA & 38.1 \\
\hline & & & ORTA & $\begin{array}{ll}5 & 41.4\end{array}$ \\
\hline & & & UZUN & $7 \quad 31.3$ \\
\hline & & & ÇOK UZUN & $9 \quad 19.2$ \\
\hline \multirow[t]{5}{*}{42} & MEYVE & Sap kalınlığı $(\mathrm{mm})$ & ÇOK INCE & 11.0 \\
\hline & & & INCE & 362.6 \\
\hline & & & ORTA & 536.4 \\
\hline & & & KALIN & 70.0 \\
\hline & & & ÇOK KALIN & 90.0 \\
\hline \multirow{2}{*}{43} & MEYVE & Kalistin görünüşü & KAPLAMASIZ & 130.3 \\
\hline & & & KAPLAMALI & $\begin{array}{ll}2 & 69.7\end{array}$ \\
\hline \multirow[t]{2}{*}{44} & MEYVE & Plesantada kapsikin varlığı & YOK & 174.7 \\
\hline & & & VAR & 925.3 \\
\hline \multirow[t]{3}{*}{45} & ÇİÇEK & Çiçek başlama zamanı (gün) & ERKEN & 326.3 \\
\hline & & & ORTA & $5 \quad 59.6$ \\
\hline & & & GEÇ & $7 \quad 14.1$ \\
\hline \multirow[t]{5}{*}{46} & MEYVE & Fizyolojik olgunluk zamanı & ÇOK ERKEN & 10.0 \\
\hline & & (gün) & ERKEN & 323.2 \\
\hline & & & ORTA & $5 \quad 59.6$ \\
\hline & & & GEÇ & $7 \quad 17.2$ \\
\hline & & & ÇOK GEÇ & 90.0 \\
\hline \multirow{3}{*}{47} & MEYVE & SÇKM (\%) & DÜŞÜK & 126.3 \\
\hline & & & ORTA & 373.7 \\
\hline & & & FAZLA & 50.0 \\
\hline \multirow[t]{3}{*}{48} & MEYVE & Etüvde Kuru Madde (\%) & DÜŞÜK & 134.3 \\
\hline & & & ORTA & 345.5 \\
\hline & & & FAZLA & $5 \quad 20.2$ \\
\hline
\end{tabular}

Çizelge 4. 2014 yılında sivri biber genotiplerinin bazı kantitatif özellikleri

\begin{tabular}{|c|c|c|c|c|c|}
\hline ÖZELLİKLER & Minimum & Genotip & Maksimum & Genotip & Ortalama \\
\hline Gövde Uzunluğu(cm) & 10.5 & $\mathrm{~S} 13$ & 21.5 & S49 & 16.56 \\
\hline Boğum Arası Uzunluğu(cm) & 3.58 & S63 & 7.48 & S59 & 5.63 \\
\hline Bitki Boy Uzunluğu(cm) & 44.8 & S63 & 72.4 & S101 & 60.24 \\
\hline Yaprak Uzunluğu(cm) & 5.18 & S69 & 8.02 & S50 & 6.20 \\
\hline Yaprak Genişliği (cm) & 2.86 & S68 & 4.36 & S63 & 3.63 \\
\hline Meyve Uzunluğu(cm) & 9.60 & $\mathrm{~S} 40$ & 20.64 & S29 & 15.97 \\
\hline Meyve Çapı $(\mathrm{mm})$ & 9.24 & S53 & 27.02 & $\mathrm{~S} 40$ & 15.98 \\
\hline M. Uzunluk/çap oranı & 3.55 & S40 & 19.77 & $\mathrm{~S} 24$ & 10.85 \\
\hline Meyve Eti Kalınlığı(mm) & 0.84 & S16 & 3.25 & S47 & 1.89 \\
\hline Meyve Sap Uzunluğu(cm) & 2.50 & S10 & 7.05 & S66 & 4.03 \\
\hline Meyve Sap Kalınlığı $(\mathrm{cm})$ & 2.00 & $\mathrm{~S} 2$ & 7.13 & S63 & 4.25 \\
\hline
\end{tabular}

Daha sonra küme analizi (cluster) uygulanarak, genotiplerin birbirleri ile benzerlik ve farklılıklarını gösteren dendrogramlar oluşturulmuştur (Düzyaman ve Duman 2004).

\section{BULGULAR}

Kırşehir ili yerel sivri biber populasyonlarının agronomik ve morfolojik özelliklerine ait frekans dağılım yüzdeleri Çizelge 3'de verilmiştir. Tanımlanması gerçekleştirilen biber genotiplerinin frekans yüzdeleri incelendiğinde sinıflandırma kriterleri yönünden oldukça geniş bir varyabilitenin olduğu belirlenmiştir. $\mathrm{Bu}$ farklılıkların özellikle, fenolojik ve meyve özelliklerinde daha belirgin olduğu saptanmıştır. Her iki gözlem yılında da genotiplerde; hipokotillerinde antosiyanin oluşumu, üst kısımda kısa boğumluluk, boğumlarda antosiyanin, tüylülük, yaprak uzunluğu ve mumsuluğu, çiçek anterlerinde antosiyanin renklenmesi, fizyolojik olgunluk öncesi renk, meyvede antosiyanin renklenmesi, meyve olgunluk rengi ve sapta oyukluk gibi özellikler \% 90’nın üzerinde aynı skala değerinde tespit edilmiştir.

Biber genotipleri arasında ölçülebilen gözlem değerleri arasında geniş bir varyasyon olduğu saptanmıştır. Çalışmada kullanılan genotip sayısı çok fazla olduğu için sadece en yüksek ve en düşük değer aralıkları ile ortalama değerler iki yıl için Çizelge 4 ve 5'de verilmiştir. Kalitatif özellikler bakımından her iki yıl belirlenen ölçüm değerleri kıyaslandığında özellikle 
gövde uzunluğu, bitki boyu ve meyve uzunluğu parametrelerinde 2014 yılında belirlenen değerlerin
2015 yılında belirlenenlerden daha yüksek olduğu saptanmiştır. .

Çizelge 5. 2015 yılında sivri biber genotiplerinin bazı kantitatif özellikleri

\begin{tabular}{llllll}
\hline ÖZELLiKLER & Minimum & Genotip & Maksimum & Genotip & Ortalama \\
\hline Gövde Uzunluğu(cm) & 8.00 & S2 & 20.27 & S9 & 13.51 \\
Boğum Arası Uzunluğu(cm) & 3.77 & S31 & 7.07 & S14 & 5.18 \\
Bitki Boy Uzunluğu(cm) & 39.16 & S11 & 65.33 & S9 & 50.98 \\
Yaprak Uzunluğu(cm) & 4.20 & S26 & 8.90 & S9 & 6.31 \\
Yaprak Genişliği(cm) & 2.33 & S27 & 5.07 & D52 & 3.33 \\
Meyve Uzunluğu(cm) & 8.20 & Maraş1 & 19.30 & S101 & 14.47 \\
Meyve Capı(mm) & 10.08 & S10 & 37.33 & TR69447S & 19.28 \\
M. Uzunluk/çap oranı & 3.19 & S28 & 19.77 & Burkalem & 8.36 \\
Meyve Eti Kalınlığ1(mm) & 1.08 & S10 & 3.25 & S34 & 1.96 \\
Meyve Sap Uzunluğu(cm) & 2.67 & S22 & 6.24 & S35 & 4.15 \\
Meyve Sap Kalınlı̆̆ı(cm) & 2.80 & S102 & 5.80 & S11 & 4.14 \\
SÇKM(\%) & 2.7 & S2-S43 & 6.3 & S68 & 4.83 \\
Etüvde Kuru Madde(\%) & 7,1 & S6 & 15.2 & S31 & 9,65 \\
\hline
\end{tabular}

Bu durumun özellikle Çizelge 1'de belirtildiği üzere 2015 yılı Haziran ayında meydana gelen aşırı yağış, kapalı havadan dolayı yetersiz ışıklanma ve nispeten daha düşük sicaklık ortalamasının oluşmasından dolayı bitki gelişiminin olumsuz etkilenmesinden kaynaklanabileceği tahmin edilmektedir.

İncelenen özelliklere Temel Bileşen Analizi (PCA) uygulanmış ve elde edilen temel bileşen eksenleri, eigen değerleri (öz değer), varyans ve toplam varyans oranları Çizelge 6'da sunulmuş̧ur. Temel bileşen analizinde eigen değeri 1'den büyük olan faktörler anlamlı olarak kabul edilmiştir. Eigen değeri 1'den küçük olan faktörler dikkate alınmamıştır (Dunteman, 1989). Uygulanan temel bileşen analizi sonucunda incelenen 48 adet tanımlama özellikleri ile ilişkili toplam 17 adet ana bileşen ekseni elde edilmiştir. $\mathrm{Bu}$ eksenler toplam varyansin \% 75.82'ini temsil etmektedir (Çizelge 6).

$\mathrm{Bu} 17$ ana bileşenin eigen değerleri 1.04 ve 5.46 arasında değişmektedir. Sekizinci ana bileşen ekseni toplam varyansın \% 50.45'ini karşılamaktadır. Verilerin faktör ağırlığının 0.30 ve üzerinde olması gerekmektedir. 0.50 ve üzerindeki ağırlıklar ise oldukça iyi olarak kabul edilmektedir (Brown, 1991; Hair ve ark., 1998). Buna dayanarak birinci grupta toplam varyansın \% 11.63'ünü oluşturan 15 özellik yer alırken bu parametrelerin büyük bir kısmı meyve ile ilgili özelliklerden kaynaklanmıştır. Meyve ile ilgili özellikler dışında sadece; yaprak uzunluğu, yaprak genişliği, kısa boğumluluk, bitki boyu ve boğumda tüylülük özellikleri bu grupta belirlenmiştir. İkinci faktörde ise ağırlıklı olarak; bitki boyu, gövde uzunluğu, çiçeklenme zamanı, yaprak enine kesitinin şekli ve yaprak şekli gibi morfolojik özelliklerin korelasyon katsayıları 0.5 'in üzerinde çıkmıştır (Çizelge 7).
En yüksek varyansı açıklayan ilk üç faktör incelendiğinde, faktör 1 için; meyve çapı, meyve uç şekli ve meyve uzunlamasına baskın şekli özelliklerinin varyansa katkısı pozitif yönde yüksek iken; meyve uzunluk çap oranı, meyve uzunluğu ve meyvede kaliksin görünüşünün etkisi negatif yönde yüksek belirlenmiştir. Faktör 2'de; bitki boyu, gövde uzunluğu ve çiçeklenme zamanı özelliklerinin varyansa katkısı pozitif yönde yüksek iken, meyvede kapsaisin varlığı negatif yönde yüksek belirlenmiştir. Faktör 3'de ise sadece meyvede gözenekler arası oluk derinliği özelliği varyansa pozitif yönde önemli katkı sağlamıştır (Çizelge 7). Kümeleme analizi sonucu oluşturulan dendrogram ise Şekil 1'de verilmiştir.

15 ana grup tespit edilen dendrogramda gruplardaki genotiplerin ortak özellikleri aşağıda belirtilmiştir.

A grubu: 15 genotip ile J grubundan sonra M grubu ile birlikte en fazla sayıda genotipi içermektedir. Grup orta ve koyu yeşil renk tonunda, acılık içermeyen, demre tipi biberlerden oluşmaktadır. D ve I grubu ile beraber en düşük SÇKM (\% 4.1) miktarına sahip olan, orta-erkenci gruptur.

B grubu: H grubundan sonra en kısa gövde boyuna (14 $\mathrm{cm}$ ), tüm gruplar içerisinde en kısa boğum arası uzunluğuna $(4.56 \mathrm{~cm})$ ve en kısa bitki boy ortalamasına $(48.36 \mathrm{~cm})$ sahip gruptur. Meyveleri açık yeşil olup, C grubundan sonra en yüksek meyve eti kalınlığına $(2.29 \mathrm{~cm})$ sahip genotipler bulunmaktadır. Fizyolojik olgunluk zamanı orta-erkencidir.

C grubu: S50 genotipinin tek başına bu grubu oluşturmasında, diğer tüm gruplardaki genotiplerin boğumlarında antosiyanin bulunmasina rağmen sadece bu genotipte bulunmamasının etkisi yüksek olmuştur. Ayrica en uzun $(8.02 \mathrm{~cm})$, en geniş $(4.44 \mathrm{~cm})$ yaprak uzunluğu ve en yüksek meyve eti kalınlığı (2.33 cm) bu grupta belirlenmiştir. 
Çizelge 6. Temel bileşen analizi sonucunda bulunan özdeğer (eigen) istatistiklerine bağlı faktör sayısı ve açıklanan varyans yüzdeleri PC EKSENLERI (TEMEL BİLEŞENLER)

\begin{tabular}{llllllllllllllllll}
\hline $\begin{array}{l}\text { Eigen } \\
\text { Değeri }\end{array}$ & 5.46 & 3.63 & 2.94 & 2.87 & 2.56 & 2.33 & 2.02 & 1.86 & 1.74 & 1.53 & 1.48 & 1.43 & 1.23 & 1.20 & 1.12 & 1.10 & 1.04 \\
\hline Varyans(\%) & 11.63 & 7.73 & 6.26 & 6.12 & 5.46 & 4.97 & 4.30 & 3.97 & 3.71 & 3.27 & 3.16 & 3.05 & 2.62 & 2.55 & 2.39 & 2.35 & 2.21 \\
\hline $\begin{array}{l}\text { Toplam } \\
\text { Varyans(\%) }\end{array}$ & 11.63 & 19.36 & 25.62 & 31.74 & 37.21 & 42.18 & 46.48 & 50.45 & 54.17 & 57.44 & 60.61 & 63.66 & 66.29 & 68.84 & 71.24 & 73.60 & 75.82 \\
\hline
\end{tabular}

Chizelge 7. Genotiplere ait özelliklerle faktörler arasındaki korelasyon katsayıları

\begin{tabular}{|c|c|c|c|c|c|c|c|c|c|c|c|c|c|c|c|c|c|}
\hline & \multicolumn{17}{|c|}{ Component } \\
\hline & 1 & 2 & 3 & 4 & 5 & 6 & 7 & 8 & 9 & 10 & 11 & 12 & 13 & 14 & 15 & 16 & 17 \\
\hline M.ÇAP & .862 & .131 & -.085 & -.017 & .099 & .045 & .021 & .089 & -.060 & -.022 & .043 & .257 & .007 & -.078 & .025 & -.075 & -.064 \\
\hline M.UZUNLUK/ÇAP & -.835 & -.100 & -.001 & .313 & .054 & -.083 & .114 & -.001 & .117 & -.044 & -.095 & -.067 & .138 & .024 & .034 & .115 & .125 \\
\hline M.UÇ.ŞEKLİ & .766 & -.034 & .224 & .238 & -.023 & -.146 & -.081 & -.014 & -.137 & .010 & -.037 & -.079 & .021 & .060 & .011 & .023 & .168 \\
\hline M.UZUNLUK & -.651 & .075 & -.205 & .393 & .178 & -.073 & .015 & .119 & .177 & -.173 & -.050 & .147 & .233 & .001 & .125 & .105 & -.001 \\
\hline M.KALİKSGÖRÜNÜŞ & -.611 & .039 & -.321 & -.073 & -.030 & .062 & -.239 & -.026 & .149 & .157 & .069 & .047 & .098 & .256 & -.084 & -.128 & .089 \\
\hline M.U.BASKIN ŞEKLİ & .607 & .010 & .251 & -.213 & -.107 & .083 & .252 & .154 & -.183 & -.019 & -.093 & .100 & .031 & -.279 & -.111 & .141 & .030 \\
\hline Y.UZUNLUK & .540 & .095 & -.474 & .252 & -.098 & -.095 & -.022 & .095 & -.198 & -.207 & .168 & .127 & .221 & .192 & .113 & .045 & .056 \\
\hline ÜST.KIS. KISA.BOĞ. & -.483 & .232 & .015 & -.377 & .026 & -.092 & .081 & -.258 & -.322 & -.198 & .106 & .033 & -.152 & -.072 & -.008 & .019 & .228 \\
\hline BİT.BOY & -.466 & .578 & -.012 & -.107 & -.290 & .012 & -.143 & .074 & -.092 & -.226 & -.067 & .006 & .094 & -.004 & -.111 & .150 & -.135 \\
\hline GÖVDE UZUNLUK & -198 & .576 & -.102 & -.096 & -.121 & .060 & -.171 & .147 & -.048 & -173 & -.202 & -.330 & .083 & .066 & .288 & .064 & -.129 \\
\hline ÇIÇEKLENME ZAM. & .180 & .553 & .256 & -.129 & -.056 & .161 & -.162 & -.456 & .076 & .121 & -.252 & .124 & .122 & .159 & -.036 & -.040 & -.041 \\
\hline Y.ENİE KES..ŞEKLİ & .059 & .516 & -.085 & .107 & .127 & -.048 & .035 & .087 & .048 & -.260 & -.155 & -.184 & -.237 & -.103 & -.501 & -.040 & .000 \\
\hline M.KAPSİSİNVARLIĞI & .021 & -.512 & .248 & -.263 & -.343 & .088 & .122 & -.233 & -.160 & .125 & .200 & -.177 & -.057 & .199 & .193 & .090 & -.070 \\
\hline Y.ŞEKLİ & .130 & .510 & -.268 & -.195 & .106 & -.288 & -.005 & .277 & .079 & .117 & .028 & .059 & -041 & -.178 & -.253 & -.173 & 103 \\
\hline M.FIZZ.OLGUNLUK & .304 & .487 & .302 & -.077 & .124 & .200 & -.038 & -.438 & .107 & .328 & -.173 & .032 & .039 & .089 & -.017 & -.032 & .022 \\
\hline M.DURUŞ & -.075 & .456 & -.254 & .122 & .100 & -.036 & .333 & .015 & -.430 & .306 & -.030 & .037 & -.089 & .023 & .231 & .214 & -.104 \\
\hline M.GÖZ.ARAOLUKDER & .298 & .288 & .547 & .161 & -.150 & .143 & .140 & .041 & .029 & -109 & .282 & -.120 & .074 & .108 & .147 & -.026 & .221 \\
\hline M.SAPUZUNLUGU & -.112 & .418 & .474 & .010 & .110 & .057 & .126 & .284 & .308 & .010 & .361 & -.093 & -.078 & -.066 & .043 & -.025 & -.060 \\
\hline Y.GENİŞLİK & .384 & .412 & -.429 & .070 & -.095 & -.197 & -.214 & .112 & -.217 & -.239 & .177 & .031 & .080 & .254 & .118 & .070 & .128 \\
\hline Y.KEN.DALGALANMA & -.131 & -110 & .397 & .268 & .290 & -.042 & -.313 & .164 & -.015 & .071 & -013 & -.053 & .173 & .078 & -.075 & -.109 & -.295 \\
\hline ETÜVDE K.M. & -.260 & -.081 & .358 & .208 & .126 & -.181 & .247 & .256 & -.280 & .045 & .107 & -.257 & .028 & -.055 & -.077 & .037 & -.264 \\
\hline M.S.HARİCİ.DALGA & -.232 & .024 & -.011 & .530 & -.309 & .239 & .386 & -.141 & -.166 & .014 & -.077 & -.032 & .043 & -.125 & .028 & -.207 & .251 \\
\hline M.S.DALGA & -.428 & .104 & -.013 & .484 & -.226 & .480 & .244 & -.006 & -.069 & -.008 & .083 & .165 & -.039 & -.127 & .057 & -.063 & 166 \\
\hline M.PLE.S.EN.BAS.ŞEK. & -.212 & -.028 & -.206 & -.484 & -.061 & .079 & -.040 & .320 & .081 & .253 & .234 & .303 & .108 & -.191 & .190 & -.103 & .175 \\
\hline M.LOKUL SAYISI & .388 & -.021 & .097 & .465 & -.149 & -.170 & .208 & .124 & .147 & -.055 & -.064 & .108 & .096 & .044 & -.078 & .126 & .219 \\
\hline BOĞ. TÜYLÜLÜK & .416 & -.017 & -.041 & .440 & -.077 & .266 & -.128 & -.105 & .103 & -.057 & -.208 & .120 & .235 & .046 & .088 & .012 & -.274 \\
\hline Y.YEŞİL RENK TONU & -.056 & .015 & .164 & .100 & .587 & -.049 & -.297 & -.053 & .001 & -.233 & -.122 & .326 & -.009 & -.037 & .189 & -.155 & .118 \\
\hline
\end{tabular}




\begin{tabular}{|c|c|c|c|c|c|c|c|c|c|c|c|c|c|c|c|c|c|}
\hline M.SAP.OYUKLUK & 146 & .065 & -.247 & -.322 & .514 & .365 & .482 & -.058 & .181 & -.181 & -.044 & -.220 & .153 & .109 & .043 & -.005 & .034 \\
\hline M.SAP.OY..DERECESI & .146 & .065 & -.247 & -.322 & .514 & .365 & .482 & -.058 & .181 & -.181 & -.044 & -.220 & .153 & .109 & .043 & -.005 & .034 \\
\hline Y.MUMSULUĞU & -.211 & .038 & .418 & .079 & .439 & .188 & -.180 & .125 & -.259 & -.078 & -.121 & .090 & .168 & -.110 & .141 & -.124 & .059 \\
\hline BİTKİ DURUŞU & .010 & -.024 & .269 & -.062 & .427 & -.055 & .076 & -.097 & .116 & .106 & .344 & .420 & .101 & .083 & -.130 & .373 & .089 \\
\hline SÜRGÜN.UZUNLUĞU & -.284 & .357 & .229 & -.254 & -.387 & -.077 & .033 & -.201 & .120 & -.260 & -.035 & .264 & .015 & -.022 & .096 & .290 & -.076 \\
\hline M.PARLAKLIK & .097 & -.208 & -.120 & .000 & .015 & .533 & -.042 & .301 & .019 & -.260 & .348 & .148 & -.157 & .177 & -.039 & .034 & .332 \\
\hline M.FİZ.RENK YOĞ. & -.017 & .073 & -.035 & .033 & .157 & .468 & -.365 & -.223 & -.303 & .058 & .155 & -.237 & -.045 & -.202 & .034 & .028 & .044 \\
\hline SÇKM & .094 & -.041 & -.304 & .089 & -.192 & .406 & -.284 & .231 & .068 & .260 & -.082 & -.115 & -.067 & -.064 & -.023 & -.012 & .114 \\
\hline ANTOSIYYANIN YOĞ. & .039 & 138 & .172 & -.110 & -.188 & .177 & .148 & .457 & .102 & 191 & -.383 & .076 & -.143 & .218 & .051 & .231 & .055 \\
\hline M.ET.KALINLIĞI & .137 & .194 & .262 & .283 & .020 & -.029 & -.176 & .106 & .480 & .007 & .157 & -.247 & -.005 & -.170 & .122 & .059 & .207 \\
\hline & -.123 & .388 & -.211 & .314 & .332 & -.123 & .171 & -.084 & -.177 & .415 & .120 & .099 & .016 & -.242 & .033 & .235 & -.238 \\
\hline HIP.ANTOSIYANIN & .027 & 130 & -.242 & -.088 & -.043 & .113 & -.296 & -.058 & .237 & .366 & .255 & -.232 & .243 & -.015 & -.057 & .223 & .086 \\
\hline BOĞ.ANTOSIYANIN & -.158 & -.076 & .102 & -.147 & -.184 & .210 & .165 & .281 & .220 & 163 & -.330 & .275 & -.020 & .113 & -.007 & -.012 & -.067 \\
\hline M.YÜZEY YAPISI & .074 & .261 & -.079 & .259 & -.304 & .310 & .041 & -.252 & .247 & -.146 & .313 & .066 & -.079 & -.116 & -.182 & .042 & -.202 \\
\hline M.ANTOSIYANİN & .023 & .249 & .300 & -.215 & -.139 & .028 & .012 & .371 & -.298 & .121 & .051 & -.182 & .487 & .118 & -.110 & -.052 & .058 \\
\hline M.FİZ.OLG.RENK & .031 & 231 & .101 & .031 & .206 & .421 & -.283 & .249 & -.154 & -.022 & -.054 & .051 & -.485 & .010 & .184 & .107 & .118 \\
\hline Y.KABARCIKLIĞI & -.100 & .217 & .178 & .098 & .111 & -.403 & .037 & -.022 & .136 & .039 & .128 & -.114 & -.369 & .404 & .177 & -.015 & .026 \\
\hline M.SAP KALINLIGI & .363 & -.031 & -.298 & .120 & .058 & -.275 & .082 & -.017 & .322 & .082 & -.149 & -.187 & -.111 & -.263 & .391 & .044 & -.127 \\
\hline Ç.ANTER..ANTO. R. & -.054 & .375 & -.112 & .239 & .023 & -.014 & .238 & -.020 & -.030 & .295 & .163 & .132 & -.108 & .332 & -.033 & -.500 & -.096 \\
\hline M.FIZ.RENK.YOĞ. & -.023 & -.283 & -.156 & .334 & .305 & .144 & -.091 & .006 & -.115 & .117 & -.122 & -.102 & -.118 & .290 & -.313 & .371 & .200 \\
\hline
\end{tabular}



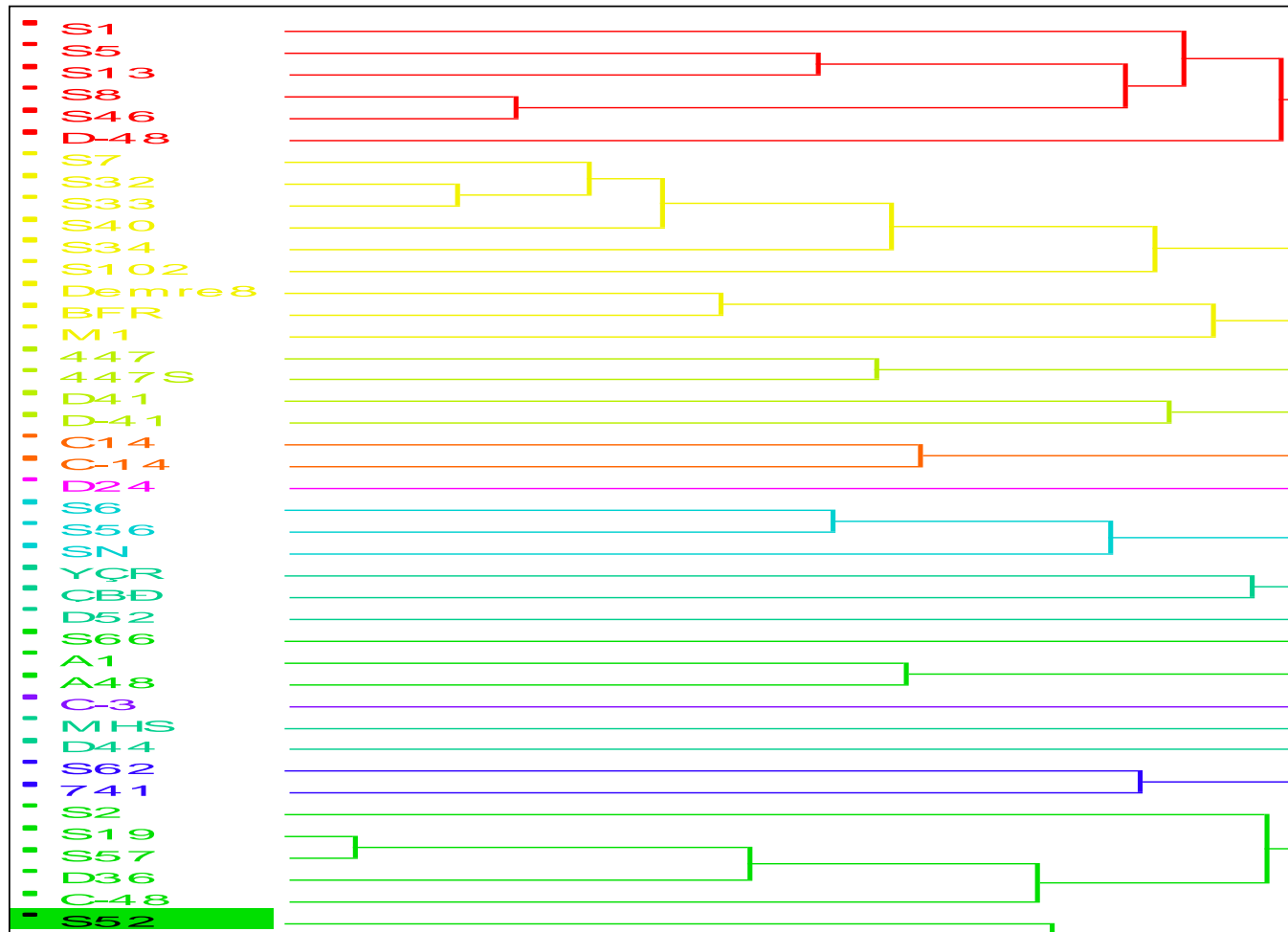

- Alm ina

- 每产1

- 510

- 531

- 523

- ycer

- 0.36

- 518

- $52=$

- 51 \%

- SRm

- 524

- 525

- 535

- 5105

- 526

- S1010

- 541

- 544

- 543

- 528

- 530
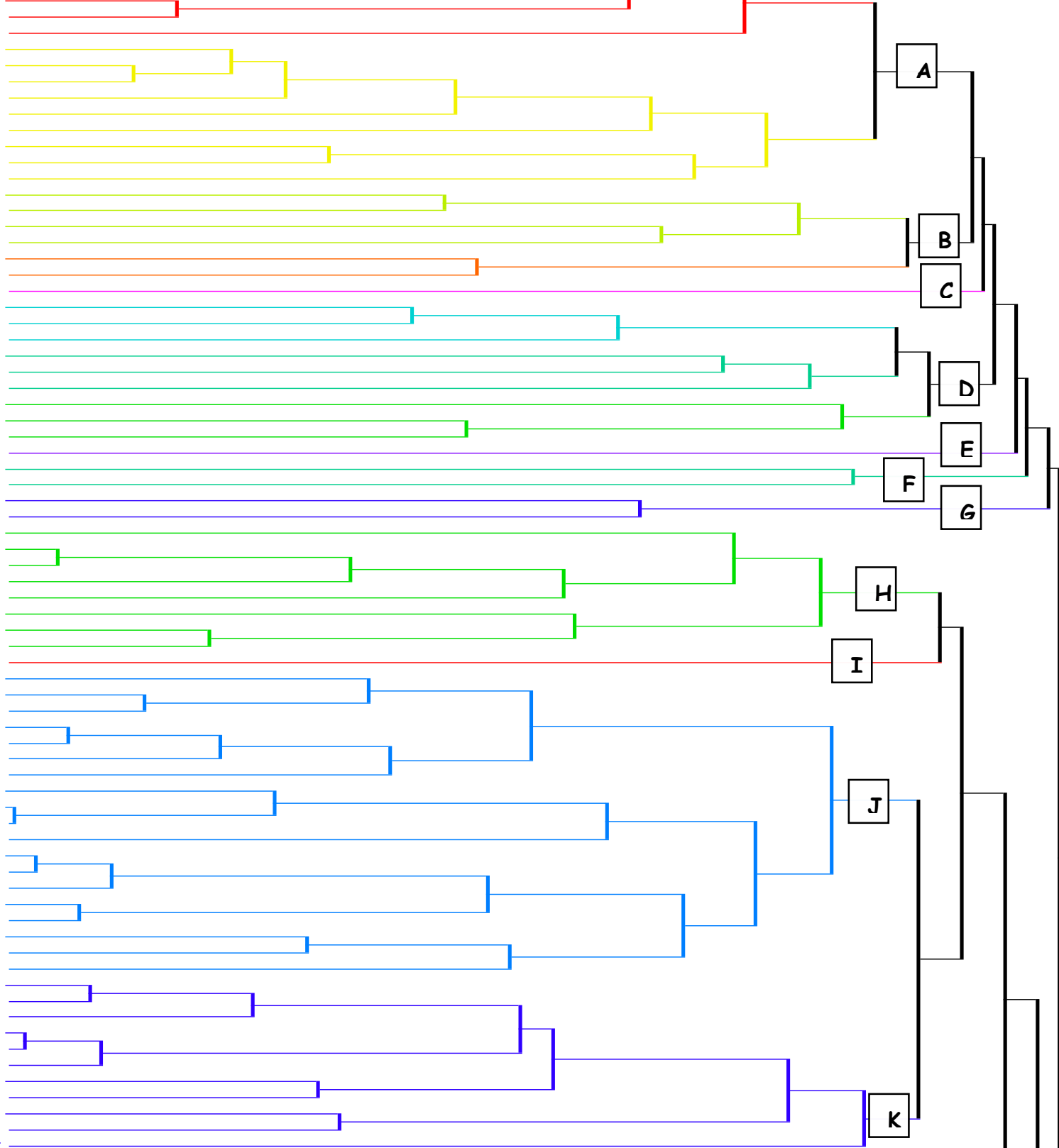

Burkalor

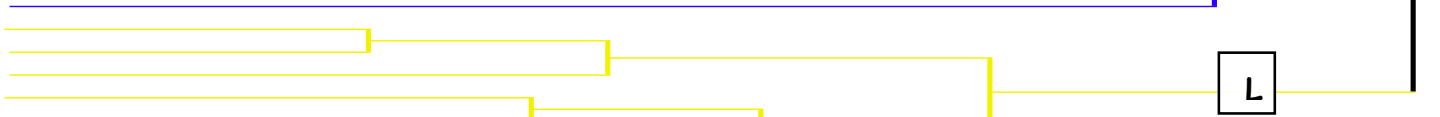

- 53

- 561

$-548$

- 211

- 54 .

$-564$

$-0_{14}$

$=545$

- 547

- 560

- 530

- 548

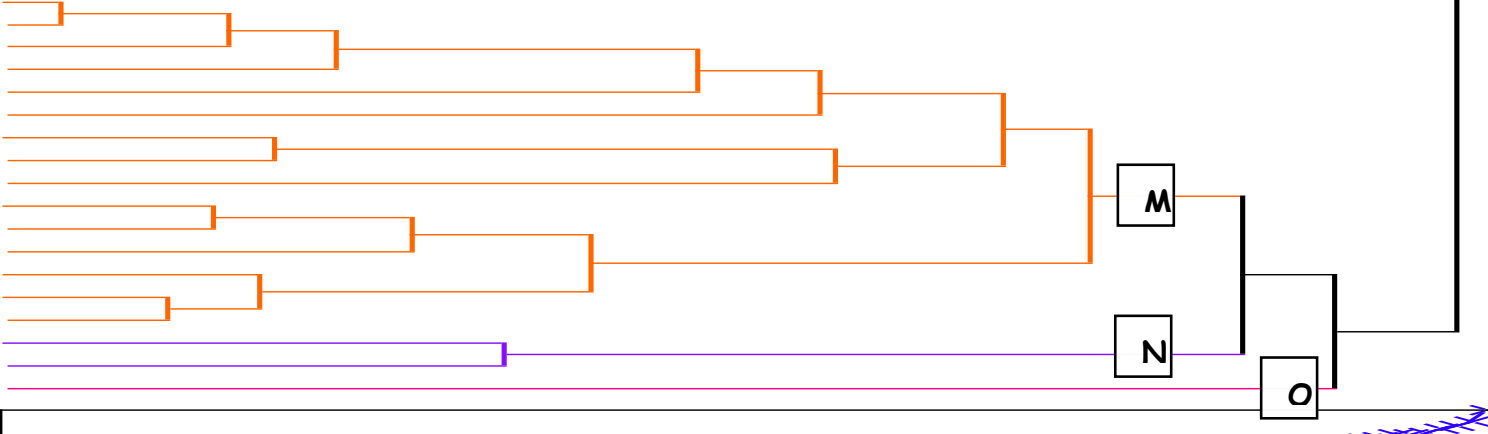

Şekil 1. Küme analizi sonucunda elde edilen dendrogram 
D grubu: Meyve boyu tüm gruplar içerisinde $12.09 \mathrm{~cm}$ ile en kısa olan gruptur. F grubundan sonra en düşük meyve uzunluk/çap oranına (5.48) sahiptir. Meyveleri ağırlıklı olarak 3 bölme sayısına sahip, meyve uzunlamasına baskın şekli boynuz şeklinde olan açık ve koyu renkli meyve tiplerinden oluşmaktadır. EKM miktarı (\% 11.6) genel ortalamanın üzerinde olsa da SÇKM miktarı (\% 4.1) en düşük gruplardan birisidir.

E grubu: Sadece S67 genotipinin bulunduğu gruptur. Diğer genotiplerde anterlerde antosiyanin renklenmesi varken sadece bu genotipte yoktur. Ayrıca meyve duruşunun dik olduğu tek genotipdir. S67 genotipi sap uzunluğu $(2.5 \mathrm{~cm})$ en kısa olan genotiptir. Erkenci, meyveleri koyu yeşil renkli, acı ve oldukça düzgün yüzey yapısına sahiptir.

F grubu: Diğer gruplardan farklı olarak üst kısımda kısa boğumluluk bulundurmamaktadır. Ayrıca diğer gruplarda boğumda tüylülük zayıf iken bu grupta orta (5) olarak belirlenmiştir. En geniş gövde çapı (31.49 mm), en düşük meyve uzunluğu/çap oranı (4.95), en yüksek sap kalınlığ $(5.21 \mathrm{~mm})$ ve en yüksek SÇKM miktarı ( $\%$ 5.7) yine bu grupta belirlenmiştir. Meyveleri çok koyu yeşil renge sahip olup, sapa yakın ve uzak kısımda güçlü dalgalanma göstermektedir.

G grubu: Sapta sığ düzeyde oyukluk gösteren tek gruptur. Düşük SÇKM (\% 4.5) ve EKM (\% 8.4) miktarına sahip, orta-geççi, sapa yakın ve uzak kısımda zayıf dalgalanma gösteren genotiplerden oluşan bir gruptur.

H grubu: En kısa gövde uzunluğuna $(13.1 \mathrm{~cm})$, en dar yaprak genişliğine $(3.1 \mathrm{~cm})$, mızrak şeklinde yaprak şekline sahip genotiplerin bulunduğu gruptur. Meyveleri ince, orta yeşil ve yüksek düzeyde acılık içerdiğinden meyveleri çok acıdır.

I grubu: Bu gruptaki tek genotip olan S31, fizyolojik olgunluk öncesi açık sarı renkte olan tek genotiptir. Meyvelerinde antosiyanin renklenmesi bulunmakta olup, meyve çapı en düşük $(9.23 \mathrm{~mm})$, meyve uzunluk/çap oranı en yüksek (17.49) olan genotiptir. EKM miktarı \% 15.2 ile tüm gruplar içerisinde en yüksek olanıdır. S31 genotipi meyve özellikleri bakımından özellikle turşu yapımında kullanımı en uygun olan genotiplerin başında gelmektedir.

J grubu: Kapsadığ 19 adet genotip ile en kalabalık gurubu oluşturmaktadır. Meyve duruşu sarkık, ağırlıklı olarak meyveleri koyu yeşil, dar üçgen şekilli, sapa yakın kısımda güçlü dalgalanma göstermektedir. Meyveleri acılık içermemekte olup, fizyolojik olgunluk zamanı ortadır. Meyve yüzeyi hafif buruşuk, SÇKM miktarı \% 5.0 ve EKM miktarı ise \% 9.2'dir.

K grubu: Bitki duruşu yarı dik, çiçek ve meyve duruşu sarkık, meyveleri orta ve koyu yeşil ve gruplar içerisinde $19.1 \mathrm{~cm}$ ile en yüksek meyve uzunluğuna sahip, meyve uzunluğu/çap oranı (17.3) I grubundan sonra en yüksek olan genotiplerin bulunduğu gruptur. Sapa yakın kısımda güçlü dalgalanma diğer gruplardan daha yüksek oranda görülen, orta-erkenci, acılık içermeyen genotiplerden oluşmaktadır. Meyve özellikleri ve verimlilik açısından özellikle sofralık tüketim için tercih edilebilir.

L grubu: Bitki duruşu dik, yaprakları açık yeşil, sapa yakın kısımda orta-güçlü dalgalanma gösteren, orta erkenci, meyve rengi orta-açık yeşil renkte olan genotipler bulunmaktadır.

M grubu: 15 genotipin bulunduğu bu grupta, $6.1 \mathrm{~cm}$ ile boğum arası en yüksek olan genotipler bulunmaktadır. Çiçeklenmeye başlama ve fizyolojik olgunluk zamanı bakımından geçci özelliktedir. L ve $\mathrm{N}$ gruplarından sonra $62.3 \mathrm{~cm}$ ile en yüksek gövde boyu ortalamasına sahiptir. Ağırlıklı olarak koyu yeşil Demre tipi biberlerden oluşmaktadır. Fizyolojik olgunluk döneminde meyveler ağırlıklı olarak açık kırmızıdır. Sadece S4 ve S64 genotiplerinin plesantalarında acılık bulunmaktadır. Çiçek başlama ve fizyolojik olgunluk zamanı bakımından geçci özelliktedir.

N grubu: Sadece 2 (S38 ve S49) genotiplerinin bulunduğu gruptur. 21 ve $71.3 \mathrm{~cm}$ ile sirasiyla en yüksek gövde uzunluğu ve bitki yüksekliğine sahiptir. $O$ ve I gruplariyla beraber meyvede antosiyanin oluşumunun görüldüğü 3 gruptan birisidir. Çiçek başlama ve fizyolojik olgunluk zamanı bakımından geçci özelliktedir. Meyveleri dar üçgen şekilli ve koyu yeşil renk tonundadır. Meyvelerde gözenekler arası oluk derinliği diğer gruplarda sığ iken N grubunda orta düzeydedir. Meyveler kapsaisin içememektedir.

O grubu: Tüm genotipler içerisinde fizyolojik olgunluk öncesi renk yoğunluğu koyu mor olan sadece S65 genotipinden oluşur. $20.6 \mathrm{~cm}$ gövde uzunluğu ve $61.6 \mathrm{~cm}$ bitki boyu ortalamasina sahiptir. Diğer guruplarda yaprakta mumsuluk zayıf iken S65 genotipinde orta düzeyde belirlenmiştir. Meyvede sapa yakın kısımda güçlü dalgalanma olmasına rağmen yüzey yapısı düzdür ve güçlü parlaktır. En yüksek meyve sap uzunluğuna $(6.01 \mathrm{~cm})$ ve SÇKM miktarına (\% 5.7) sahip genotiptir. Meyveleri acılık içermeyen, orta erkenci bir genotiptir.

Küme analizi sonucu belirlenen akrabalık derecesi (distance) 2.77-17.67 arasında değişirken; S18-S22 ile S41-S44 genotiplerinin birbirine çok benzer; S1-S2, S1-S62, S2-S3, S1-S9 ve S2-TR69737 genotiplerinin ise agronomik ve morfolojik varyabilite bakımından birbirine en uzak genotipler olduğu belirlenmiştir. Islah çalışmalarında birbirine en uzak akraba genotipler arasinda yapilacak melezlemeler ile yüksek pozitif heterosis oranı yakalanabilmektedir. 


\section{TARTIŞMA ve SONUÇ}

Islah çalışmalarında türler içerisindeki mevcut agronomik ve morfolojik varyasyonların bilinmesi ve bu varyasyonunun dağılış durumunun ortaya konulması önemli avantajlar sağlamaktadır (Gil ve Ron 1992; Balkaya ve Ergün 2008). Birçok bitki türünde olduğu gibi, farklı kaynaklardan temin edilmiş biber genotiplerinin agronomik ve morfolojik karakterizasyonu da birçok araştırmacı tarafından yapılmıştır (Berletti ve Quagliotti, 1982; Gonzalez ve Azurdia, 1985; Pentcheva, 1987; Cole, 1993; Carvalho ve ark., 2003; Zewdie ve ark., 2004; Duman ve Düzyaman, 2004; Keleş ve ark., 2004; Karaağaç, 2006; Keleş, 2007; Mutlu ve ark., 2009; Bozokalfa ve Eşiyok 2010; Sürmeli ve Erdoğan, 1985). Ancak genelde bu tür çalışmaların gen bankalarından materyal temin edilmesi şeklinde gerçekleştirilmesinden dolayı, materyaller toplandıkları coğrafik ve ekolojik koşulların dışındaki şartlarda da incelenebilmektedir. Her ne kadar iyi bir çeşitte aranan özelliklerden birisi de farklı ekolojik koşullarda da üstün adaptasyon yeteneği göstermesi olsa da, pratikte bazen bu durum gözlenemeyebilir. $\mathrm{Bu}$ sebeple morfolojik ve agronomik karakterizasyon çalışmalarında materyallerin daha sağlıklı bir şekilde değerlendirilebilmesi için öncelikle toplanıldığı ekolojik koşullarda veya benzer koşullarda tanımlanmasının yapılması daha uygun olabilir.

Islah çalışmalarında kullanılacak materyallerin yüksek varyasyon göstermesi istenilen bir durumdur (Gözen, 2008; Bozokalfa ve Eşiyok, 2010). Islahta heterojen bir gen havuzundan istenilen özelliklere sahip bitkilerin seçilebilmesi hedefe ulaşmayı kolaylaştırmaktadır. Biber bitkisinde yapılan önceki morfolojik karakterizasyon çalışmalarında sonuçlarımızla uyumlu şekilde; Karaağaç ve Balkaya (2010), Bafra ovasindan toplanan 56 adet kırmızı biber popülasyonuna 20 değişken esas alınarak yaptıkları küme analizinde 8 grup tanımlamışlardır. Temel Bileşen Analizinde ilk üç PC ekseni toplam varyansın \% 74.3’ünü açıklamıştır. Bozokalfa ve Eşiyok (2010), 2004 yılı için 48, 2005 yılı için toplam 94 biber genotipinde 67 agronomik ve morfolojik özellik bakımından karakterizasyon çalışması yapmış, denemenin birinci yılında \% 77.50'lik varyabilite 11 komponent grubunda, ikinci yılda ise toplam \% 71.52'lik varyabilite 10 grupta saptamışlardır. Binbir (2010), 26 biber genotipini 54 morfolojik özellik bakımından karakterize etmiş, genotiplerin biber tiplerinin birçoğunu içermesinden dolayı geniş varyasyon gösterdiğini bildirmiştir. Temel bileşen analizinde toplam çoklu varyasyonun \%85.35'ini temsil eden 9 adet PC ekseni oluştuğunu, gruplar arası benzerlik dendogramının esas olarak 3 farklı grup oluşturduğunu belirlemiştir. TBA analizinde toplam varyasyonun $\% 25$ ve daha fazlasinin, ilk 2 ya da 3 eksen tarafindan açıklanabilmesi ve temel bileşen eksenlerinin toplam varyasyonun 2/3'ünü açıklaması durumunda küme analizi daha güvenilir olmaktadır (Mohammadi ve Prasanna, 2003; Özdamar, 2004). Zewdie ve Zeven (1997), toplam varyansin \%58'inin ilk altı PC ekseninde temsil edildiğini; Keleş (2007), ilk üç PC ekseninin toplam varyansın \% 50'sini temsil ettiğini belirlemişlerdir. Önceki çalışmalar ile kıyaslandığında, bu çalışmada toplam varyans \% 75.82 gibi yüksek bir değerde belirlenmesine rağmen, ilk üç PC ekseninde kümülatif varyasyonun \% 25.62'de kalması denemede ticari çeşitler hariç sadece Kırşehir ilinden toplanan materyallerin kullanılmasından kaynaklandığı düşünülmektedir. Belirlenen varyans çok yüksek olamasa da genotipler arasından varyabilitenin bulunduğunu göstermektedir.

Çalışmada incelenen genotipler, sivri biber tiplerinin çoğunu içermesinden dolayı bitki ve meyve özellikleri açısından geniş bir varyasyon göstermiştir. Denemenin her iki yılında da ağırlıklı olarak meyve ile ilgili özelliklerin korelasyon katsayıları yüksek çıkmıştır. Birinci grupta toplam varyansın \% 11.63’ünü oluşturan 16 özelliğin 10 tanesi meyve ile ilgili agronomik ve morfolojik özelliklerden oluşturmuştur. Bulgularımızla benzer şekilde bir çok araştırmacı da tespit edilen varyasyonun büyük bir kısmının meyve ile ilgili agronomik ve morfolojik özelliklerden kaynaklandığını bildirmiştir (Mutlu ve ark.,2009; Duman ve Düzyaman, 2004; Bozokalfa ve Eşiyok, 2010). Meyve özellikleri açısından yüksek varyabilitenin oluşmasında, biberde yüksek oranda görülen yabancı tozlanmanın etkisi önemlidir. Zira çiftçi koşullarında izolasyon mesafesine uyulmadan yapilan tohumluk temininde en fazla meyve özellikleri etkilenmektedir.

Önemli bir kalite parametresi olan SÇKM miktarının yüksek olması özellikle salça endüstrisinde istenilen bir özellik olmasına rağmen, kurutmalık ve endüstriyel amaçlı kullanılan sivri biberler içinde bu durum geçerlidir. $\mathrm{Bu}$ çalışmada tüm genotiplerde SÇKM miktarı \% 2.7-6.3 aralığında değişmiştir. Benzer şekilde Karaağaç ve Balkaya (2010), çalışma yaptıkları kapya genotiplerinde SÇKM miktarlarının \% 5.0-7.6 arasında değiştiğini, Sürmeli ve Erdoğan(1985) \% 6.0-7.6 arasinda değiştiği bildirmişlerdir. Bu çalışmada etüvde kuru madde miktarı \% 7.1-15.2 arasında değişirken, benzer şekilde Ahmed ve ark.(1996), sivri biber genotiplerinde \% 7.17-14.67 arasında değiştiğini, Karaağaç ve Balkaya (2010) \% 7.3 ile 13.5 arasında değiştiğini bildirmişlerdir.

Kümeleme analizi sonucu 15 ana grup tespit edilen dendrogramda; A, D, H, K, L ve M gruplarinda en az iki ve üzeri ticari çeşit bulunurken, diğer gruplarda hiçbir ticari çeşit yer almamıştır. Bu sonuç, popülasyonda belirlenen varyans üzerine bölgeye 
önceden giren ticari çeşitlerin etkisinin olabileceğini göstermesi bakımından önemlidir.

$\mathrm{Bu}$ çalışmada Kırşehir sivri biber popülasyonunun agronomik ve morfolojik özellikler yönünden tanımlanması yapılarak hem mevcut varyasyon durumu ortaya çıkarılmış hem de ileride yapılacak biber ıslah çalışmaları için nitelikli gen havuzlarının oluşturulmasına katkı sağlanmıştır. Ayrıca morfolojik ve agronomik verilere göre yapılan sinıflandırmanın ileride bu genotiplerle yapılacak moleküler düzeydeki çalışmalarla daha etkin şekilde belirlenebilmesi mümkün olacaktır.

\section{TEŞEKKÜR}

Bu çalışma Kırşehir Ahi Evran Üniversitesi Bilimsel Araştırma Projeleri Koordinatörlüğü (BAP) tarafindan PYO-ZRT.4001.13.009 numaralı proje kapsamında desteklenmiştir. İstatistiksel analizlerin yapılmasında yardımlarından dolayı Öğr.Gör. Gülcan BAŞAK’a teşekkür ederiz.

\section{KAYNAKLAR}

Ahmed N, Tanki MI, Mir M, Shah GA 1996. Effects of Different Fruit Maturity Stages and Storages Conditions of Chemical Composition and Market Acceptability of Fruit In Different Varieties of Sweet Pepper. Capsicum and Eggplant Newsletter, 16: 47-60.

Anonymous 1994. Pepper (Capsicum annuum L.) Guidelines for the Conduct of Tests for Distinctness, Uniformity and Stability. Int. Union for the Protection of New Varieties of Plants (UPOV) TG/76/7. p. 33.

Balkaya A ve Ergun A 2008. Diversity and use of pinto bean (Phaseolus vulgaris) populations from Samsun, Turkey. New Zealand Journal of Crop and Horticultural Sci. 36: 189-197

Berletti P, L Quagliotti 1982. Collection and Evaluation of Pepper Germplasm. Institute of Plant Breeding and Seed Production Uni. of Turin Via P. Giuria 15, 10126 Turin, Italy. Capsicum Newsletter, No:1 1982 S. 13-14.

Binbir S, Baş T 2010. Bazı Yerel Biber (Capsicum annuum L.) Populasyonlarının Karakterizasyonu. Anadolu: Ege Tarımsal Araştırma Enstitüsü Dergisi (J. of AARI), 20 (2): 70-88.

Bliss FA 1981. Utilization of vegetable germplasm. Proceedings of the Symposium. Hortscience, Vol. 16(2): 129-132.

Bozokalfa K, Eşiyok D, Turhan K 2009. Patterns of phenotypic variation in a germplasm collection of pepper (Capsicum annuum L.) from Turkey. Spanish Journal of Agricultural, 7(1): 83-95.

Bozokalfa MK, Eşiyok D 2010. Biber (Capsicum annuum L.) aksesyonlarında genetik çeşitliliğin agronomik özellikler ile belirlenmesi. E.Ü. Ziraat Fak. Derg., 47(2): 123-134.
Brown JS 1991. Principal component and cluster analysis of cotton cultivar variability a cross the U.S. Cotton Belt. Crop Science, 31: 915-922.

Carvalho SIC, Bianchetti LB, Henz GP 2003. Germplasm collection of Capsicum spp. maintained by Embrapa Hortaliças. Capsicum and Eggplant Newsletter 22: 17-20.

Cole PS 1993. Evaluation and Increase of USDA Capsicum Germplasm. Department of Agronomy and Horticulture, New Mexico State University, Las Cruces, New Mexico, USA. Capsicum and Eggplant Newsletter No: 121993 S: 39-41.

Dunteman GH 1989. Principal Components Analysis. Thousand Oaks, CA: Sage Ppublications, Quantitative Applications in the Social Sciences Series, No.69.

Düzyaman E, Duman İ 2004. Türkiye'de Yetiştirilen Bazı Önemli biber genotiplerinin morfolojik varyabilitesi üzerine bir araştırma. E.Ü.Z.F. Derg. 41(3): 55-66.

FAO 2014. FAOSTAT Statistical Databases [http://www.fao.org/] Erişim Tarihi: 10.02.2016.

Gil J ve Ron AM 1992. Variation in Phaseolus vulgaris in the Northwest of the Iberian Peninsula. Plant Breeding 109: 313-319

Gonzalez MM, Azurdia CA 1985. Capsicum Characterization in Guatemala. Agricultural Sciences and Technology Institute and Agronomy Schcool of Universidad de Sn. Carlos, Guatemala, C.A. Capsicum Newsletter No: 41985 S: 16 .

Gözen V 2008. Hiyarda (Cucumis sativus L.) örtüaltı yetiştiriciliğine uygun hibrit çeşit ıslahında morfolojik karakterizasyon, hibrit kombinasyonları ile hibrit tohum verim ve kalitesinin belirlenmesi. Ankara Üniversitesi, Fen Bilimleri Enstitüsü, Bahçe Bitkileri Anabilim Dalı, Doktora Tezi, 185 s, Ankara.

Hair JF, Anderson RE, Tatham RL, Black WC 1998. Multivariate Data Analysis, Prentice Hall, NewJERSEY.

Haussmann BIG, Parzies HK, Presterl T, Susic Z, Miedaner T 2004. Plant genetic resources in crop improvement. Plant Genetic Resources, 2(1): 3-21.

Karaağaç O 2006. Bafra kırmızı biber gen kaynaklarının (Capsicum annuum var. conoides Mill). karakterizasyonu ve değerlendirilmesi. Ondokuz Mayıs Üniversitesi, Fen Bil. Enst., Bahçe Bitkileri Ana Bilim Dalı, Yüksek Lisans Tezi, 129 S Samsun.

Karaağaç O, Balkaya A 2010. Bafra Kırmızı Biber Populasyonlarinin [Capsicum annuum L. var. conoides (Mill.) Irish] Tanımlanması Ve Mevcut Varyasyonun Değerlendirilmesi. Anadolu Tarım Bilimleri Dergisi. 25(1):10-20.

Keleş D 2007. Farklı biber tiplerinin karakterizasyonu ve düşük sicaklığa tolerans. Çukurova Üniversitesi, Fen Bil. Enst., Bahçe 
Bitkileri Anabilim Dalı, Doktora Tezi, 182 sy, Adana.

Keleş D, Karagül S., Büyükalaca S 2004. Characterization of different pepper genotypes collected from coastal regions of Turkey. 17th International Pepper Conference November 14-16, in Naples, Florida, USA

Küçük A 1996. Plant Genetic resources Activities in Turkey. European Cooperative Programme for Crop Genetic Resources Networks (ECP/GR), Third Meeting, Rome, Italy. 69-75.

Mohammadi SA, Prassana BM 2003. Analysis Of Genetic Diversity in Crop Plants-Salient Statistical Tools and Considerations. Crop Sci., 43:1235-1248.

Mutlu S, Haytaoğlu MA, Kır A, İçer B 2009. Ulusal Gen Bankası Biber (Capsicum Annuum L.) Materyalinde Morfolojik Karakterizasyon. Anadolu: Ege Tarımsal Araştırma Enstitüsü Dergisi (J. of AARI), 19 (1): 63-91.

Özdamar K 2004. Paket Programlar ile İstatiksel Veri Analizi (Çok Değiskenli Analizler). 5. Baskı. 528s.

Pentcheva T 1987. Characteristics of Some Local Peppers. Institute of Introduction and Plant genetic Resources 'K. Malkov' Sadova, Plovdiv, Bulgaria. Capsicum Newsletter No: 61987 S.15.

Sneath PHA ve Sokal RR 1973. Numerical taxonomy the principles and practice of numerical classification (W. H. Freeman: San Francisco).
Sürmeli N, Erdogan S 1985. Yağlık (Salçalık) biber 1slahı. Bahçe Dergisi 14 (1-2) 31-35

Şalk A, Arın L, Deveci M, Polat S 2008.Özel Sebzecilik, Namık Kemal Üniversitesi Ziraat Fakültesi, 448 s., Tekirdăg.

Tan A 1992. Türkiye'de bitkisel çeşitlilik ve bitki genetik kaynakları. Anadolu, J. of AARI. 2(2): 5054.

Tan A, Inal A 2003. Ege Tarımsal Araştırma Enstitüsü bitki genetik kaynakları çalışmaları, Ege Tarımsal Araştırma Enstitüsü Müdürlüğü Yayın No:112, 13 s., İzmir.

TUIK 2017. Türkiye İstatistik Kurumu (TUIK) Bitkisel Üretim İstatistikleri [http://www.tuik. gov.tr/bitkiselapp/bitkisel.zul] Erişim Tarihi: 15.02.2018.

Vural H, Eşiyok D, Duman İ 2000. Kültür sebzeleri. Ege Üniversitesi Basımevi, $440 \mathrm{~s}$.

Zewdie Y, Tong N, Bosland PW 2004. Establishing a core collection of capsicum using a cluster analysis with enlightened selection of accessions. Genetic Resources and Crop Evolution 51: 147-151.

Zhang XM, Zhang ZH, Gu XZ, Mao SL, Li XX, Chadœuf J, Palloix A, Wang LH, Zhang BX 2016. Genetic diversity of pepper (Capsicum spp.) germplasm resources in China reflects selection for cultivar types and spatial distribution. Journal of Integrative Agriculture, 15 (9): 1991-2001. 